\title{
Bacterial Pathogens and Antibiotic Susceptibility Patterns of Cervico-Vaginal Discharges in Cross Bred Repeat Breeding Heifer Cows
}

\author{
Ankit Kumar Ahuja ${ }^{1 *}$, Ranjna Sandhey Cheema ${ }^{2}$, Deepti Narang ${ }^{3}$ and \\ Shahbaz Singh Dhindsa ${ }^{4}$
}

\author{
${ }^{1}$ Department of Veterinary Gynecology and Obstetrics, ${ }^{2}$ Department of Veterinary Microbiology, \\ ${ }^{3}$ Department of Animal Genetics and Breeding, College of Veterinary Science, Guru Angad Dev \\ Veterinary and Animal Sciences University, Ludhiana, Punjab, India \\ *Corresponding author
}

\begin{tabular}{|c|c|}
\hline & A B S T R A C T \\
\hline & \multirow{5}{*}{$\begin{array}{l}\text { The type of bacterial isolation and their susceptibility patterns to various antibiotics are } \\
\text { necessary to eliminate the uterine infections. The present study was designed to isolate and } \\
\text { compare the bacterial pathogens and antibiotic susceptibility in Cervico-vaginal discharges } \\
\text { of normal cyclic, repeat breeder and heifer cows. For this purpose } 43 \text { cows without any } \\
\text { significant detectable pathologic disorders of reproductive tract were selected. The cows } \\
\text { were divided into three groups viz. Group A (n=11) normal cyclic, Group B }(\mathrm{n}=16) \text { repeat } \\
\text { breeder and Group C ( }=16) \text { heifers cows. Cervico - vaginal discharges were collected } \\
\text { with the help of AI gun covered with sheath. } 54.5(6 / 11), 68.7(11 / 16) \text { and } 12.5 \%(2 / 16) \\
\text { bacterial growth was found in Group A, B and C, respectively. Only single isolates of } \\
\text { bacteria were found in Group A while } 72.7 \text { and } 50 \% \text { were found in Group B and C, } \\
\text { respectively. Further, double isolates were found in } 27.3 \text { and } 50 \% \text { Group B and C. E. coli } \\
\text { and Streptococcous were highly ( }>50 \%) \text { sensitive to ceftriaxone, ciprofloxacin, amoxyclav } \\
\text { and tetracycline while Bacillus to ciprofloxacin and tetracycline followed by ciprofloxacin, } \\
\text { tetracycline and amoxyclav against Staphylococcus. In conclusion higher isolates of } \\
\text { Staphylococcous were found in Normal cyclic cows while Bacillus in repeat breeding } \\
\text { cows. Equal isolates of Bacillus, E. coli and Streptococcus were found in heifer cows. }\end{array}$} \\
\hline $\begin{array}{l}\text { K e y w o r d s } \\
\text { Cervico - vaginal } \\
\text { discharge, Bacill } \\
\text { Ciprofloxacin }\end{array}$ & \\
\hline Article Info & \\
\hline $\begin{array}{l}\text { Accepted: } \\
\text { 23 May } 2017 \\
\text { Available Online: } \\
\text { 10 June } 2017\end{array}$ & \\
\hline & \\
\hline
\end{tabular}

\section{Introduction}

Well managed and profitable dairy farming requires animal with good reproductive performance (Nebel and Jobst, 1998). However, various reports of decreasing profit in dairy farming have been identified where improvements can be made (Bishop, 1964). Of them, postpartum uterine infection is the majorcause of economic loss in dairy cows (Fox et al., 2002; Sriskandan et al., 2000). It may be due to a longer calving interval, costs of extra services, treatment and increased culling rate (Drillich et al., 2005; Gilbert et al., 2005). Fertility of cow is affected by many nonspecific and specific pathogens of the genital tract. Uterine environment favors the growth of anaerobic organisms which in turn promotes the growth of various pathogenic aerobes that act synergistically to cause bacterial infection (Huszenicza et al., 1999). A higher percentage of cows (80 to $100 \%$ ) found positive for bacterial contamination of the uterus in the first 2 
weeks postpartum (Foldi et al., 2006). Most of these bacterial contaminations get eliminated during the first 5 weeks after parturition, but the remaining causes the uterine infection in some cows (Noakes et al., 2009; Sheldon et al., 2006). Common bacteria isolated from cows with uterine infections are Trueperella pyogenes, Prevotella sp., Fusobacterium necrophorum and Escherichia coli (Sheldon et al., 2006; Lewis, 1997; Smith et al., 1998; Overton et al., 2003and Sheldon et al., 2004).

Bacillus, Streptococcus, Enterococcus and coagulase negative Staphylococci are the most frequently isolated uterine bacteria that can act as opportunistic pathogens or contaminants (Westermann et al., 2010; Werner et al., 2012).

The presence of pathogenic bacteria in the uterus causes inflammation and histological lesion of endometrium.

Intra uterine antibiotics are one component often used in the treatment of uterine infections. For adequate treatment of the infection there is a need of rapid microbiological diagnosis.

Major advantages of intrauterine treatment with antibiotics are reduced interval of treatment, rapid recovery rate and improved conception rate but their unselective use has led to development of resistant bacterial strains making further use of such therapy useless (Arora et al., 2000). The effectiveness of such therapeutic agents needs to be evaluated repeatedly to treat drug resistance bacterial strains. Therefore present study was planned to analyze the presence of bacterial pathogens in uterine environment of normal cyclic, repeat breeder and heifers cows with an aim to isolate / identify the bacteria and also to investigate the antibiotic sensitivity to suggest the treatment for the control of such infection.

\section{Materials and Methods}

A total of 43 cows without any detectable pathologic disorders of reproductive tract were selected from the University Dairy Farm. On the basis of number of AI and their parity cows were divide into three groups, Group A - normal cyclic ( $\mathrm{n}=11)$, Group Brepeat breeder $(\mathrm{n}=16)$ and Group C-heifers $(n=16)$. Cervico - vaginal discharge (CVD) was collected in sterilized vials from the cows in heat with the help of AI gun covered with sheath and immediately shifted to the lab of Microbiology department, GADVASU, Punjab, India. Collected cervico vaginal discharges were inoculated by streaking on BHI (Brain-heart infusion) and blood agar media.

The inoculated media was incubated at $37^{\circ} \mathrm{C}$ and observed after every 12 hours till 48 hours post inoculation for the incidence of any progress. Physical characteristics of the isolates were noted and cultures were refined by sub culturing in BHI broth and were chilled. The characterization of each isolate was done on the basis of staining behavior, size, motility, biochemical and cultural tests. Overnight incubation of representative samples $(n=13)$ of isolated colonies was done in nutrient broth at $37^{\circ} \mathrm{C}$.

To cover the Muller- Hinton agar medium evenly with bacterial suspension we used a sterile cotton swab that was dipped in the bacterial suspension and then rolled over its surface. Seven different antibiotic discs were positioned over the surface of the agar plate. For this purpose, discrete antibiotic discs (Himedia, Mumbai) containing Amoxyclav $30 \mu \mathrm{g}$, Cefotaxim $30 \mu \mathrm{g}$, Ampicillin $10 \mu \mathrm{g}$, Tetracycline $30 \mu \mathrm{g}$, Ciprofloxacin $5 \mu \mathrm{g}$, Cefuroxime $30 \mathrm{mg}$ and Ceftriaxone $30 \mu \mathrm{g}$ per discs were used. Sensitivity or resistance to antibiotic was checked by measuring the diameter of inhibition zone found according to Bauer-Kirby scale. 


\section{Results and Discussion}

Percentage of isolation and the type of bacteria isolated were different among groups. In Group A, 6 out of 11 normal cycling (54.5\%), 11 out of $16(68.7 \%)$ repeat breeders in Group B and 2 out of 16 (12.5\%) heifersin Group $\mathrm{C}$ were found positive for bacterial growth. In Group B, 8 out of 11 positive samples showed single isolates and 3showed double isolates. Among the positive repeat breeder cows (Group B), 8 were found positive for endometritis while rest of them didn't show any change in cervco vaginal discharge. Among 23 isolated colonies, Group B showed maximum number (14) followed by Group A (6) and Group C (3).

Maximum number of double isolates was also shown by Group B indicating the higher percentage of mixed infections in repeat breeders (Table 1).

There were total 14 colonies isolated in repeat breeder cows (Group B) and bacteria were $57.1 \%$ Bacillus sp., $14.3 \%$ each of $E$ coli, Staphylococcus sp. and Streptococcus sp. (Figures 1 and 2). It indicates that main cause of infection in (Group B) was Bacillus sp. Infection with Staphylococcus sp.was highest (50 \%) in normal cycling cows (Group A) whereas, infection was equal i.e. $33.3 \%$ with all three bacteria (Bacillus sp., E coli and Streptococcus sp.) in heifers (Group C). During the present study $68.7 \%$ repeaters were found positive for bacterial isolates, which was higher than normal cycling (54.5 $\%)$ and heifers $(12.5 \%)$. The predominant bacteria isolated from repeaters were Staphylococcus sp., Bacillus sp., Streptococcus sp. and E coli. Among the four bacteria found in 23 isolated colonies, Bacillus sp. was found in higher percentage (43.5\%) (Table 2).
The result of antibiotic sensitivity test in the current study indicated that maximum number of isolates was highly sensitive to Ciprofloxacin (100\%) and Tetracycline (90.25\%), moderately sensitive to Ceftriaxone (56.5\%) and Amoxyclav (49\%) and least sensitive to Cefotaxim (26\%), Cefuroxime (25\%) and Ampicillin (15\%) among group of bacteria isolated (Table 3 ).

Results indicate higher percentage of bacterial growth in repeat breeder cows as compared to normal cycling cows and heifers. Higher positivity of $89,91.12$ and $91.11 \%$ in repeat breeder groups were reported in previous years (Zahid, 2004; Shukla and Sharma, 2005 and Zaman et al., 2015). A similar study revealed higher percentage of bacteria isolated from the mucopurulent vaginal discharge of repeat breeding cows $(69.6 \%)$ compared to normal cyclic discharge (30.4\%) (Gani et al., 2008).

In a study, $16.9 \%$ repeat breeders positive for bacterial isolation shows clinical abnormality of vaginal discharge and $45.8 \%$ repeat breeder cows having no clinical signs (Singh et al., 1998). Previous reporting of bacterial isolations in relation to services indicates they were higher in cows with repeated services of 5 times or more than heifers and normal cycling cows (Rahman et al., 1984).

A study revealed $56.10 \%$ cows with single type of organism and $43.90 \%$ samples yielded more than one type of organisms from repeat breeder cows (Zaman et al., 2015). Various reports of mixed infections (Chandrakar et al., 2002; Das et al., 1996; Dholakia et al., 1987 and Abd El-Kader and Shehata, 2001) from the vaginal discharges suggest that pathogens act synergistically to cause bacterial infection (Huszenicza et al., 1999). 
Table.1 Bacterial examination of normal cycling-, repeat breeder-cows and heifers

\begin{tabular}{|c|c|c|c|c|c|c|c|c|c|c|}
\hline \multirow[t]{3}{*}{ Group } & \multirow{3}{*}{$\begin{array}{l}\text { No. of } \\
\text { examined } \\
\text { animals }\end{array}$} & \multicolumn{4}{|c|}{ Presence of bacteria } & \multirow{3}{*}{$\begin{array}{l}\text { No. of } \\
\text { colonies }\end{array}$} & \multicolumn{4}{|c|}{ No. of animals with } \\
\hline & & \multicolumn{2}{|c|}{ Present } & \multicolumn{2}{|c|}{ Absent } & & \multicolumn{2}{|c|}{ Single isolate } & \multicolumn{2}{|c|}{ Double isolate } \\
\hline & & No. & $\%$ & No. & $\%$ & & No. & $\%$ & No. & $\%$ \\
\hline Normal cycling cows & 11 & 6 & 54.5 & 5 & 45.5 & 6 & 6 & 100 & - & 0 \\
\hline Repeat breeder cows & 16 & 11 & 68.7 & 5 & 31.3 & 14 & 8 & 72.7 & 3 & 27.3 \\
\hline Heifers & 16 & 2 & 12.5 & 14 & 87.5 & 3 & 1 & 50 & 1 & 50 \\
\hline Total & 43 & 19 & 44.1 & 24 & 55.9 & 23 & 15 & 65.2 & 4 & 17.4 \\
\hline
\end{tabular}

Table. 2 List of microorganisms isolated from 23 cows and heifer

\begin{tabular}{|c|c|c|}
\hline Bacteria & Cows & Percent \\
\hline E. coli & 5 & 21.7 \\
\hline Bacillus & 10 & 43.5 \\
\hline Staphylococcus & 5 & 21.7 \\
\hline Streptococcus & 3 & 13.1 \\
\hline Total & 23 & 100 \\
\hline
\end{tabular}

Table.3 Percentage of susceptibility of the isolated strain to the different antibiotics

\begin{tabular}{|c|c|c|c|c|}
\hline \multirow{2}{*}{ Antibiotic } & \multicolumn{4}{|c|}{ Bacteria } \\
\cline { 2 - 5 } & $\begin{array}{c}\text { E.coli } \\
(\mathrm{n}=4)\end{array}$ & $\begin{array}{c}\text { Bacillus } \\
(\mathrm{n}=7)\end{array}$ & $\begin{array}{c}\text { Staphylococcus } \\
(\mathrm{n}=3)\end{array}$ & $\begin{array}{c}\text { Streptococcus } \\
(\mathrm{n}=4)\end{array}$ \\
\hline Ceftriaxone & $100(4)$ & $42.85(3)$ & $33.33(1)$ & $50(2)$ \\
\hline Ciprofloxacin & $100(4)$ & $100(7)$ & $100(3)$ & $100(4)$ \\
\hline Amoxyclav & $50(2)$ & $28.57(2)$ & $66.67(2)$ & $50(2)$ \\
\hline Tetracycline & $75(3)$ & $85.71(6)$ & $100(3)$ & $100(4)$ \\
\hline Ampicillin & $0(0)$ & $14.28(1)$ & $0(0)$ & $0(0)$ \\
\hline Cefotaxim & $25(1)$ & $28.57(2)$ & $0(0)$ & $25(1)$ \\
\hline Cefuroxime & $25(1)$ & $0(0)$ & $0(0)$ & $25(1)$ \\
\hline
\end{tabular}

Fig.1 Showing isolated bacteria from the cervico vaginal discharge of positive animals. a) Bacillus, b) E. coli, c) Streptococcus, d) Staphylococcus

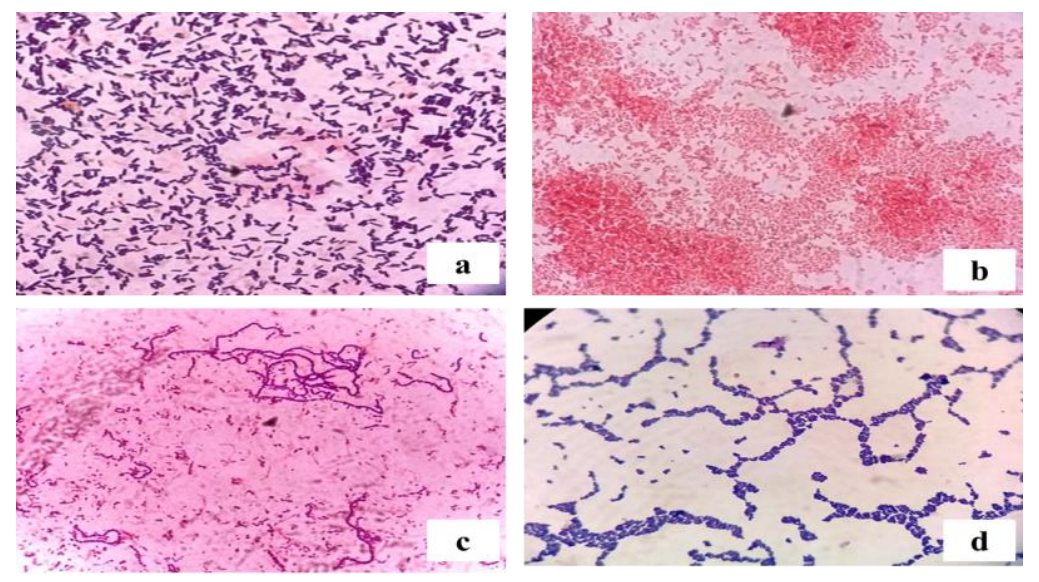


Fig.2 Diagram percentage isolation of different bacteria form group A, B and C

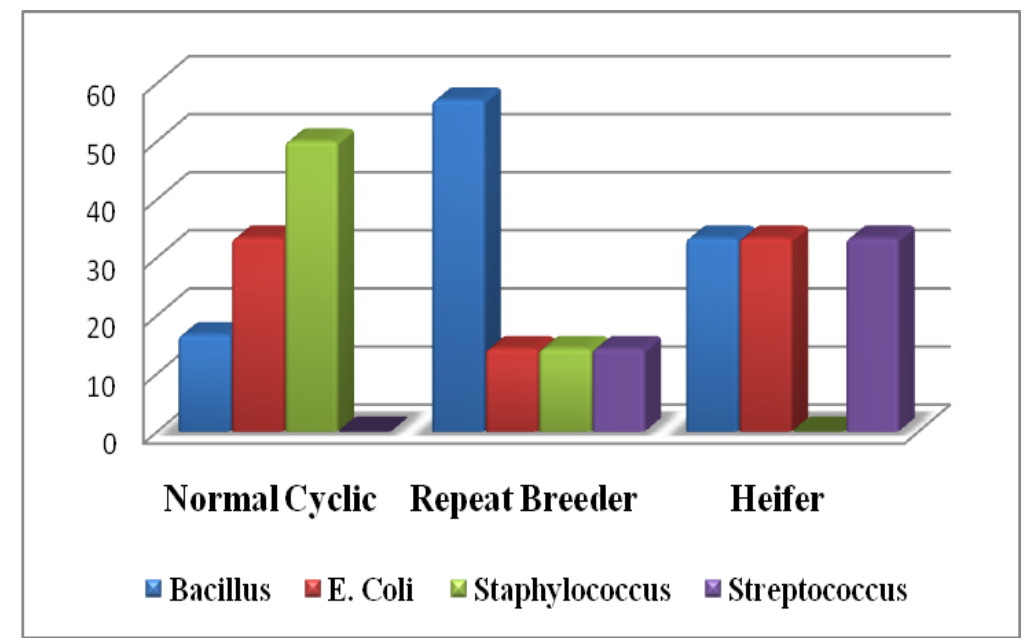

The susceptibility of bacteria Bacillus sp. and E. coli are more or less effective against 7 antibiotic agents and Amoxicillin, Oxytetracycline and Ciprofloxacin are moderate to highly sensitive to the all of isolates (Gani et al., 2008). Previously it was reported that bacterial isolates was highly sensitive to Ciprofloxacin (Zaman et al.,2015, Bhattacharya,2004) but effect of Gentamicin was not the same, this may be due to the over use of Gentamicin during the last few years (Sharma et al., 1993). Based on in vitro drug sensitivity Ciprofloxacin was used in all repeat breeding cows through intrauterine route at the uniform dose rate of $1320 \mathrm{mg}$ daily for three consecutive days (Singla et al., 2004) and they were artificially inseminated in next estrus and the pregnancy diagnosis was done per rectally after 45 days. Ciprofloxacin was also found highly sensitive (60-100\%) for four types of isolates followed by Tetracycline (three isolates, 60-100\%), Ceftriaxone (two isolates, 60-100 \%) and Amoxyclav / Cefotaxim (one isolate, 60\%) during the present study. The antibiotic susceptibility patterns needs to be evaluated time and again to decide the best available treatment for the uterine infections and to overcome the problem of drug resistance.
It can be concluded that Bacillus sp. followed by Staphylococcus sp. and E. coli were the common opportunistic bacteria in normal cyclic, repeat breeder and heifers cows that can any time turn into synergistic pathogen and cause the affections of female genital tract. And Ciprofloxacin and Tetracycline was come out to be highly sensitive drug.

\section{Acknowledgements}

The authors are thankful to University Grant Commission (UGC), New Delhi for providing grant (F.No. 41-830/2012/SR) under major research projects. Apart from this I sincerely thank Microbiology department and Dairy farm for timely collection of sample and for guiding me in microbial isolation.

\section{References}

Abd El-Hafeez, M.M., Abd El-Kader, H.A., Sayed, A.M., Shehata, S.H., 2001. A bacteriological study on bovine endometritis, with special reference to its treatment with honey infusion. Assiut Medical Journal, 45 (89): 289302.

Arora, A.K., Singh, J., Pangaonkar, G.R., Nanda, A.S., 2000. Bacteriological 
studies on the genital infection in repeat breeder bovines. Indian Journal of Animal Reproduction.21: 146-147.

Bhattacharya, A., 2004. Bacteriological and mycological study on the uterine discharge of repeat breeding cattle in Tripura.Indian Veterinary Journal.81: 721-722.

Bishop, M.W.H., 1964. Paternal contribution to embryonic death.Journal of Reproduction and Infertility. 30:383396.

Chandrakar, D., Tiwari, R.P., Awasthi, M.K., Hirpurkar, S.D., 2002.Microbial profile, their antibiogram pattern in cervicouterine contents and conception rate following treatment in repeat breeder crossbred cows.Indian Journal of Animal Reproduction.23(2): 148- 150.

Das, K.L., Misra, P.R., Kar B.C., Roy, P.K., 1996. Aerobic bacterial isolates and their antibiogram in repeat breeder cows. Indian Veterinary Journal.900902.

Dholakia, P.M., Shah, N.M., Purohit, J.H., Kher, H.N., 1987. Bacteriological study on non-specific genital infection and its antibiotic spectra in repeat breeders. Indian Veterinary Journal.64 (8): 637640.

Drillich, M., Raab, D., Wittke, M., Heuwieser, W., 2005. Treatment of chronic endometritis in dairy cows with an intrauterine application of enzymes: A field trial. Theriogenology. 63: 18111823.

Foldi, J., Kulcsar, M., Pecsi, A., Huyghe, B., Lohuis, C., Huszenicza, G.P., 2006.Bacterial complications of postpartum uterine involution in cattle. Animal Reproduction Science. 96: 265281.

Fox, K.L., Born, M.W., Cohen, M.A., 2002. Fulminant infection and toxic shock syndrome caused by Streptococcus pyogenes. Journal of Emerging
Medicine. 22(4):357-366.

Gani, M.O., Amin, M.M., Alam, M.G.S., Kayesh, M.E.H., Karim, M.R., 2008. Bacterial flora associated with repeat breeding and uterine infections in dairy cows. Bangladesh Journal of Veterinary Medicine.6: 79-86.

Gilbert, R.O., Shin, S.T., Guard, C.L., Erb, H.N., Frajblat, M., 2005.Prevalence of endometritis and its effects on reproductive performance of dairy cows. Theriogenology. 64(9):18791888.

Huszenicza, C.R., Fodor, M., Gacs, M., Kulesar, M., Dohmen, M.J.W., Vamos, M., 1999. Uterine bacteriology, resumption of cyclic ovarian activity and fertility in postpartum cows kept in large dairy breeds herds. Reproduction in Domestic Animals.34: 237-245.

Lewis, G.S., 1997. Uterine health and disorders. Journal of Dairy Science.80: 984-994.

Nebel, R.L., Jobst, S.M., 1998. Evaluation of systemtic breeding programs for lactating dairy cows: a review. Journal of Dairy Science. 81:1169-1174.

Noakes, D.E., England, G.C.W., 2009. Veterinary reproduction and obstetrics. $9^{\text {th }}$ Edition Philadelphia, USA. Saunders Elsevier. pp. 411-417.

Overton, M.W., Sischo, W.M., Reynolds, J.P., 2003. Evaluation of effect of estradiol cypionate administered prophylactically to postparturient dairy cows at high risk for metritis. Journal of American Veterinary Medical Association. 223:846-851.

Rahman, H., Dutta, J.C., Boro, B.R., 1984. Studies on the bacterial flora of repeat breeder cows in Assam.Indian Veterinary Journal.8 (9): 183-84.

Sharma, S.S., Gupta, A.K., Bishnoi, B.L., Pareek, P.K., Rawat, M., 1993. Antibiotic sensitivity pattern of microorganisms causing endometritis in 
cattle. Indian Journal of Animal Reproduction.14 (2): 116-117.

Sheldon, I.M., Dobson, H., 2004. Postpartum uterine health in cattle.Animal Reproduction Science. 82-83:295-306.

Sheldon, I.M., Lewis, G.S., LeBlanc, S., Gilbert, R.O., 2006. Defining postpartum uterine disease in cattle. Theriogenology. 65:1516-1530.

Shukla, S.P., Sharma, R.D., 2005. Bacteriological studies on uterine biopsy and conception rate following treatment in repeat breeding crossbred cows. Indian Journal of Animal Reproduction.26 (1): 17-19.

Singh, M., Sharma, M., Pant, H.C., 1998. Microbiological study on cervical mucus of repeat breeder cows in Himachal Pradesh. Indian Veterinary Journal. 75 (8): 710-712.

Singla, P., Singh, N.S Sharma, J., Dhaliwal, G.S. and Ajeet K., 2004 Effect of post A.I. Immunotherapy on dynamics of uterine micro $\square$ ora and conception in subclical endometritis cows, Indian Journal of Animal Science. 74: 706-70.

Smith, B.I., Donovan, G.A., Risco, C., Littell, R., Young, C., Stanker, L.H., Elliott, J., 1998. Comparison of various antibiotic treatments for cows diagnosed with toxic puerperal metritis. Journal of Dairy Science 81:1555- 1562.

Sriskandan, S., Kemball-Cook, G., Moyes,
D., Canvin, J., Tuddenham, E., Cohen, J., 2000. Contact activation in shock caused by invasive group A Streptococcus pyogenes. Critical Care Medicine. 28(11):3684-3691.

Werner, A., Suthar, V., Plontzke, J., Heuwieser, W., 2012. Relationship between bacteriological findings in the second and fourth week's postpartum and uterine infection in dairy cows considering bacteriological results. Journal of Dairy Science.2012; 95, 7105-7114.

Westermann, S., Drillich, M., Kaufmann, T.B., Madoz, L.V., Heuwieser, W., 2012.A clinical approach to determine false positive findings of clinical endometritis by vaginoscopy by the use of uterine bacteriology and cytology in dairy cows. Theriogenology.74: 12481255.

Zahid, I.A., 2004. Culture and sensitivity of bacterial growth from exotic cows suffering from endometritis under Pakistani conditions. Pakistan Veterinary Journal.24 (2): 107-108.

Zaman, M.I., Sharma, U., Taku, A.K., Kumar, S., Kumar, S., 2015.Therapeutic Studies and Microbial Profile in Repeat Breeding Cows. Indian Veterinary Journal. 92 (8): 56 - 58.

\section{How to cite this article:}

Ankit Kumar Ahuja, Ranjna Sandhey Cheema, Deepti Narang and Shahbaz Singh Dhindsa. 2017. Bacterial Pathogens and Antibiotic Susceptibility Patterns of Cervico-Vaginal Discharges in Cross Bred Repeat Breeding Heifer Cows. Int.J.Curr.Microbiol.App.Sci. 6(6): 1769-1775. doi: https://doi.org/10.20546/ijcmas.2017.606.205 